https://www.scilook.eu/index.php/slif/article/view/slif23-01-012 DOI: 10.30888/2415-7538.2021-23-01-012

\title{
УДК 640.412
}

\section{MAIN DIRECTIONS OF IMPLEMENTATION OF SERVICE ROBOTICS IN AIRPORT TERMINALS \\ ОСНОВНІ НАПРЯМИ ВПРОВАДЖЕННЯ СЕРВІСНОЇ РОБОТИЗАЦЇ̈ В ТЕРМІНАЛАХ АЕРОПОРТІВ}

Biliakovych O.М. / Білякович О.М.

c.t.s., doc. / к.m.н., доu..

ORCID: 0000-0003-3887-3715

Kurbet L.V./Курбет Л.B. assistant/асистент

ORCID: 0000-0002-2244-939X

Tsiupak M.S./ Цюпак М.C. student/cmудентка

Koniushyna A.I./ Конюшина A.I. student/cтудентка

National Aviation University, Kiev, Liubomyra Huzara, 1, 03058 Національний авіаційний університет, Київ, Любомира Гузара, 1, 03058

Анотація. У даній роботі розглянуті та систематизовані сучасні роботизовані системи у пасажирських терміналах аеропортів, акцентовано увагу на багатовекторності подібних технічних інновацій. Їх впровадження є свідченням намагання аеропортів постійно вдосконалювати рівень психологічного і побутового комфорту авіапасажирів.

Ключові слова: сервісна роботизачія, реєстрачія пасажирів, оформлення багажу, авіаційна безпека, управління аеропортом, психологічний комфорт, аеровокзальний комплекс.

\section{Вступ.}

Сучасна інноваційна політика у сфері розвитку пасажирських авіаційних перевезень вимагає від провідних аеропортів світу впровадження додаткових сервісних послуг для потенційних користувачів інфраструктурою аеропорту. Перш за все йдеться про подальший розвиток різноманітних систем, що сприятимуть зростанню рівня комфорту, безпеки та зменшенню кількості стресових ситуацій, на які наражаються авіапасажири в аеровокзальних комплексах, особливо у період пандемії.

Одним iз ефективних шляхів вирішення вищезазначених проблем $\epsilon$ впровадження у практику обслуговування клієнтів пасажирських терміналів аеропортів, так званої, сервісної роботизації.

За прогнозами аналітичної компанії Market Research Future (MRFR) світовий ринок роботів для аеропортових терміналів значно зросте в період 3 2021 по 2027 рік при середньорічних темпах зростання в 16,8\% [1].

Сервісні роботи для аеропортів на сьогоднішній день - це прогресивна концепція, що реалізується в потужних міжнародних аеропортах світу. Із швидким розвитком сучасних технологій майбутня роботизація аеропортових послуг стає цілком очевидною, іï впровадження в аеропортах буде неухильно зростати.

\section{Основний текст.}

Світове виробництво сервісної робототехніки для аеропортів пов'язано, 
перш за все, з діяльністю таких визнаних компаній як ABB Ltd, LG Electronics Inc., SoftBank Corp., Stanley Robotics, SITA, YUJIN ROBOT Co., Ltd., Universal Robots A / S., ECA GROUP, Avidbots Corp, Cyberdyne Inc тощо.

Можна навести ряд конкретних прикладів, де подібні системи або проходять промислові випробування, або вже впевнено функціонують.

В аеропорту Інчхон у Сеулі пасажири вже звикли бачити роботів, що знаходяться навколо них. Зокрема, робот Airstar, розроблений компанією LG, допомагає пасажирам орієнтуватися в аеропорту - виводить на монітор вказівки щодо напрямку руху та знаходить необхідні стійки реєстрації. Для цього пасажиру достатньо було просто надати роботу Airstar свій номер рейсу. Варто зазначити, що цей робот може спілкуватися різними мовами, він оснащений технологією штучного інтелекту (АI) та системою розпізнавання голосу. Робот також здатний надати пасажирам різноманітну корисну інформацію про аеропорт, об'єкти інфраструктури терміналів [2].

Роботизовані інвалідні коляски 3 автономним управлінням, розроблені компанією WHILL, проходять тестування в Міжнародному аеропорту Ханеда (Токіо) [3].

Автономна коляска здатна перевозити одну людину на відстань близько 600 метрів по заздалегідь запрограмованому маршруту. За допомогою сенсорного екрану користувачі можуть самостійно обрати необхідний пункт призначення в будь-якому місці аеровокзалу. Використовуючи дані пристрої, у інвалідів і літніх людей більше не буде необхідності звернення за допомогою до персоналу аеропорту.

Роботизована інвалідна коляска переміщається по аеропорту за допомогою вбудованої навігаційної системи. Після завершення необхідного маршруту руху вона самостійно повертається на док-станцію, підзаряджається та готова до обслуговування наступного клієнта.

У продовження цієї теми варто згадати про відому японську фірму All Nippon Airways (ANA), яка 32020 року продовжує серію успішних випробувань самокерованих інвалідних візків у Міжнародному аеропорту Наріта (Токіо).

У найближчий час планується впровадження даних роботизованих пристроїв у вищезазначеному аеропорту [4].

Прес-служба Міжнародного аеропорту Пітсбурга стверджує, що він став першим аеропортом США, в якому для очищення використовуються автономні роботи з технологією ультрафіолетової дезінфекції [5].

Роботизована технологія призначена для знищення мікробів i вірусів у місцях 3 інтенсивним трафіком пасажирів, а також для підвищення чистоти громадських зон та відновлення довіри 3 боку мандрівників до безпеки перельотів.

Дезінфікуючі роботи $є$ першим проектом аеропорту, в якому використовуються технологічні інновації для вирішення проблем, викликаних поширенням коронавірусної інфекції Covid-19. Впровадження роботів стало можливим завдяки співпраці аеропорту 3 місцевою компанією Carnegie Robotics. На сьогодні аеропорт Пітсбург $є$ єдиним у США, в якому 
використовують автономних роботів не тільки для очищення підлог, а й для дезінфекції ультрафіолетовим випромінюванням поручнів ескалаторів i траволаторів, кнопок ліфтів та інших місць 3 підвищеною кількістю торкань.

Аеропорт Абу-Дабі в партнерстві з Дубайським фондом стратегічного розвитку Tawazun (TSDF) також планує впровадити безпілотного робота CoDi BOT UGV для боротьби з поширенням коронавірусної інфекції в терміналах повітряної гавані [6].

Даний робот був розроблений і виготовлений в ОАЕ місцевою компанією Marakeb Technologies. Робот має низку унікальних особливостей. Зокрема, CoDi BOT UGV вміє маневрувати в салонах літаків, забезпечуючи їх чистоту i стерильність. Дане робототехнічне рішення може передавати відео зображення в реальному часі, використовуючи для цього високошвидкісну 4G передачу даних.

Міжнародний аеропорт Даллас Форт-Уерт в кінці червня 2019 року запустив в Терміналі D роботизовану систему Vanderlande FLEET, яка допоможе пасажирам швидко здавати свій багаж. В аеропорту заявили, що це перша подібна роботизована система, здатна обробляти майже 450 одиниць багажу на годину. Технологія тестується на транзитних пасажирах, які мають стикувальні рейси через аеропорт Далласа [7].

Клієнти, які беруть участь в пілотній програмі, зможуть використовувати одну 3 чотирьох self-bag drop станцій для здачі багажу. За допомогою сенсорного екрану транзитний пасажир обирає авіакомпанію свого стикувального рейсу, багажний робот FLEET забирає валізу і перевозить на відповідну багажну стрічку для завантаження на борт літака.

Міжнародний аеропорт Наріта представив чотири нових робота-охоронця, які будуть використовуватися для патрулювання i забезпечення безпеки в терміналі токійської повітряної гавані [8].

Робот має висоту 1,20 метра і для руху використовує колеса. Крім того електронний охоронець оснащений системами безпеки, в тому числі камерою відеоспостереження 3 круговим оглядом, датчиками тепла i металу. Експлуатація роботів розпочалась в аеропорту з червня 2020 року.

Роботи-охоронці в японському аеропорту допоможуть знизити навантаження звичайних охоронців. Зокрема, роботи перевіряють за допомогою зонда сміттєві контейнери, виявляють загоряння і стежать за правопорядком, передаючи всі дані на станцію моніторингу.

Вони зможуть переміщатися всередині будівель терміналу по запрограмованому курсу, використовуючи датчики руху, щоб уникнути перешкод під час маневрування.

В аеропортах Нью-Йорка і Сан-Франциско голландська авіакомпанія «KLM Royal Dutch Airlines» запустить пілотний проект по впровадженню навігаційних роботів Care-E, які допоможуть супроводити пасажирів з багажем до потрібного гейту [9].

Знайти потрібний вихід на посадку в величезних аеропортах із затримками i змінами гейтів, часом стає складним завданням для авіапасажирів. Авіакомпанія «KLM Royal Dutch Airlines» планує запропонувати пасажирам 
максимально зручне i швидке переміщення по терміналах аеропорту за допомогою мобільного малогабаритного робота.

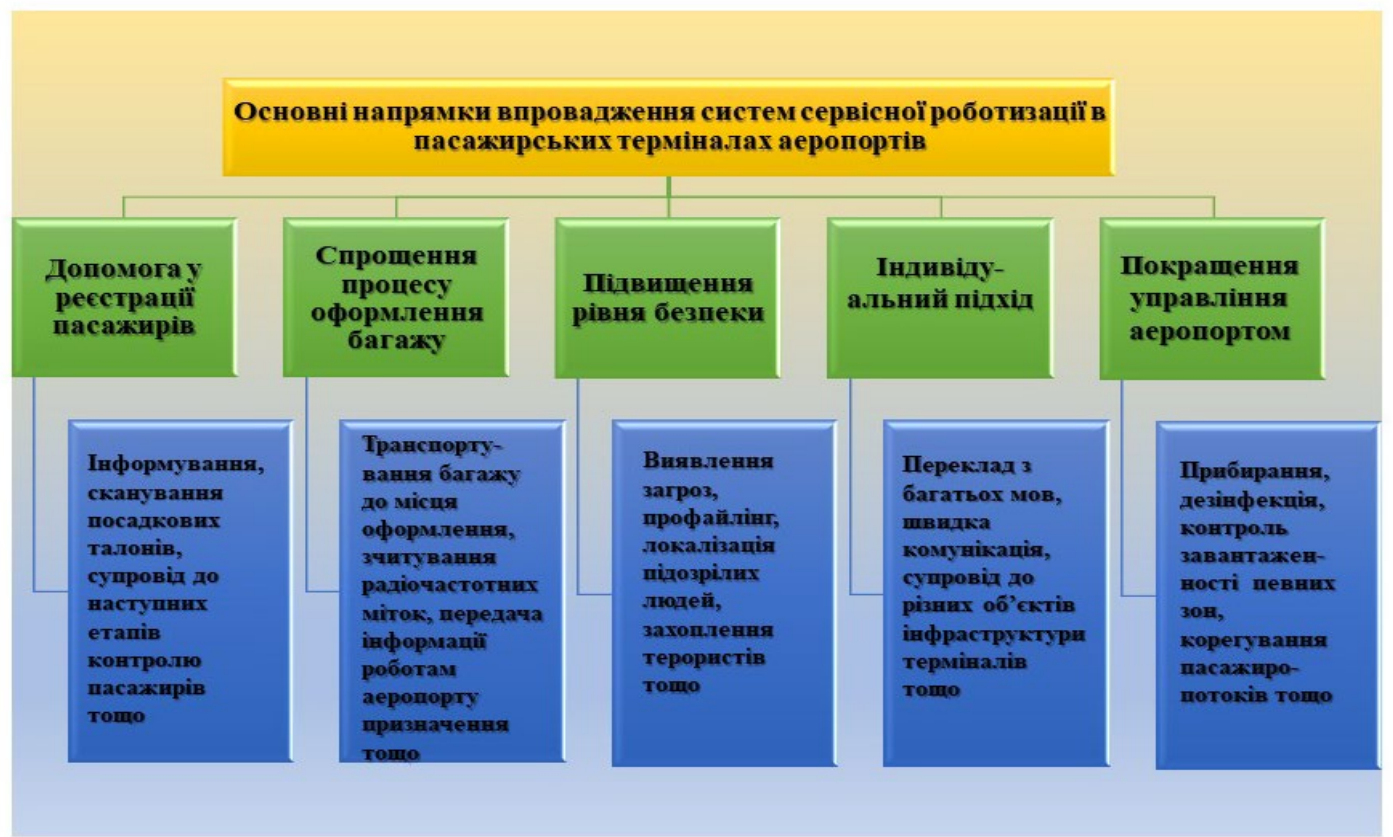

\section{Рисунок 1 - Основні напрямки впровадження сервісних роботів у пасажирських терміналах аеропортів} Авторська розробка

Робот Care-Е готовий зустріти клієнта авіакомпанії на контрольнопропускному пункті і відвести його туди, куди йому потрібно, прихопивши 3 собою ручну поклажу пасажира. Care-Е переміщається зі швидкістю близько 5 км/год. Щоб скористатися послугами робота клієнту авіакомпанії потрібно тільки відсканувати свій посадковий талон.

Сервісні роботи можуть повністю замінити обслуговуючий персонал аеропортів вже до 2030 року, таких висновків у проведеному дослідженні дійшли аналітики компаній Aira i Vero Solutions [10]. У майбутньому роботи замінять існуючі способи реєстрації пасажирів, отримають доступ до даних про клієнтів у режимі реального часу та визначатимуть фізичний та емоційний стан авіапасажирів.

\section{Висновок.}

Вищенаведений огляд продемонстрував очевидну перспективність щодо впровадження в терміналах аеропортів сучасних роботизованих систем (рис. 1). Причому, вражає багатовекторність подібних технічних інновацій - від роботів для консультативної допомоги авіапасажирам та реєстрації квитків і багажу до проведення санітарно-епідеміологічних заходів, що особливо актуально в умовах пандемії.

Реалізація роботизованих систем на сьогодні є свідченням намагання аеропортів постійно вдосконалювати рівень сервісних послуг для клієнтів, а отже, підвищення психологічного і побутового комфорту авіапасажирів, стимулюючи тим самим зростання довіри та бажання скористатись послугами як конкретного аеропорту, авіакомпанії, так і авіаційної галузі у цілому. 
Література:

1. Global Airport Robots Market Research Report [електронний ресурс] Режим доступу: https://www.marketresearchfuture.com/reports/airport-robotsmarket-10563

2. Incheon Airport Introduces «AIRSTAR», Passenger Aiding Robot [електронний ресурс] - Режим доступу: http://koreabizwire.com/incheon-airportintroduces-airstar-passenger-aiding-robot/121298

3. Japan Airlines to trial WHILL autonomous wheelchairs at Haneda Airport [електронний pecypc] - Режим доступу: https://www.airporttechnology.com/news/whill-autonomous-wheelchair-haneda-airport/

4. ANA to Expand Self-driving Wheelchair Tests at Narita Airport [електронний pecypc] - Режим доступу: https://www.anahd.co. ip/group/en/pr/201910/20191009.html

5. Pittsburgh Becomes First US Airport To Deploy UV Cleaning Robots [електронний ресурс] - Режим доступу: https://simpleflying. com/pittsburgh-uvrobots/

6. Abu Dhabi Airports to deploy new technology to counter COVID-19 [електронний pecypc] - Режим доступу: https://www. gulftoday.ae/business/2020/05/02/abu-dhabi-airports-to-deploy-new-techno logy-tocounter-covid-19

7. Dallas Fort Worth Airport Rolls Out Mobile Baggage Robots [електронний pecypc] - Режим доступу: https://www.roboticsbusinessreview.com/ news/ dallasfort-worth-airport-rolls-out-mobile-baggage-robots/

8. Japan's Narita airport to use security robots in run-up to Olympics [електронний ресурс] - Режим доступу: http://www.xinhuanet.com/ english/201905/30/c_138102975.htm

9. This ridiculously cute robot will carry your luggage at the airport [електронний ресурс] - Режим доступу: https://mashable.com/article/klm-luggagetrolley-roboto-care-e-

10. Robots to take over our airports by 2030 [електронний ресурс] - Режим доступу: https://www.traveldailymedia.com/robots-take-over-airports-by-2030/

Abstract. This paper considers and systematizes modern robotic systems in airport passenger terminals, focuses on the multi-vector nature of such technical innovations. Their introduction is evidence of the efforts of airports to constantly improve the level of psychological and domestic comfort of air passengers.

Key words: service robotics, passenger registration, baggage clearance, aviation security, airport management, psychological comfort, airport complex.

Стаття відправлена: 28.11.2021 p.

(C) Білякович O.M. 